\title{
Impact of Federal Funds Rate on Monthly Stocks Return of United States of America
}

\author{
Sarfaraz Javed ${ }^{1}$, Baaeth Atallah Aldalaien ${ }^{2}$, Uvesh Husain ${ }^{1} \&$ Mohammed Shahfaraz Khan ${ }^{3}$ \\ ${ }^{1}$ Assistant Professor, Economics and Business Studies Department, Mazoon College, Oman \\ ${ }^{2}$ Lecturer, College of Business Administration, Ajman Univerity, UAE \\ ${ }^{3}$ Assistant Professor, Rustaq College of education, Oman \\ Correspondence: Sarfaraz Javed, Assistant Professor, Economics and Business Studies Department, Mazoon \\ College, Oman. E-mail: Sarfaraz.javed@mazcol.edu.om
}

Received: April 20, 2019

doi:10.5539/ijbm.v14n9p105
Accepted: May 22, 2019

Online Published: August 5, 2019

\begin{abstract}
This study examines the impact of federal funds rate on monthly stocks return of the United States of America. The study made use of secondary data from 31st January 1980 to 31st December 2009 gotten from Fred Economic Data and Economic Research Federal Reserve Bank of St. Louis and the Ordinary Least Square Method was applied to perform the analysis using Eviews 9.0. The findings of this study reveal that before the crisis, the rate of interest significantly predicted monthly stock return while during the crisis; the rate of interest did not significantly predict monthly stock return. In addition, the growth rate of industrial production significantly predicted monthly stock return with while FFR did not significantly predict monthly stock return. Likewise, change in FFR significantly predicted monthly stock return while the growth rate of industrial production did not significantly predict monthly stock return.
\end{abstract}

Keywords: Monthly stock return, Federal funds rate, the Growth rate of industrial production, Rate of Interest

\section{Introduction}

Financial policy activities have an important and powerful influence on the returns of the stock market. The stockmarket is unstable and has several factors that determine the prices of stock as well as worldwide events, firm's performance, policies changes, alteration in interest rates and the likes. Such alterations and events may result in a higher market value in some stocks and lower market values in others, whereby the total impact can alternate via alterations in stock market index. In general, Federal Funds Rate (FFR), which is put in place by the Federal Open Market Committee (FOMC) is known as the rate of interest which federal funds are transacted within the depository firms. Federal funds are the balances set aside at the Federal Reserve by depository firms. It is referred to as the interest rate at which commercial banks lend funds from federal funds to other banks and this is obtained from the variation in demand and supply of funds. The rate varies based on the position of the supply of money from commercial banks and the loan demanded by other banks. The FFR influences the financial and monetary state, which resulted in other effects on major issues like inflation, employment, the rate of dollar, growth and loans. The connection between these issues can be expatiated as; high rate of FFR shows that banks will limit the rate of borrowing reserves because of higher charges. In order to generate more funds, they will have to increase rates of interest, which will have a direct effect on the spending of companies and individuals as spending will minimize.

Bomfim (2003) and Sarfaraz (2017) indicated that the application of day-to-day data might reduce the accuracy of the influence of the news projected because of further financial data, which could be made available to the public later that same day. He also stressed that optimistic shock in FFR target rate alteration is likely to reflect a higher impact on the day-to-day instability of S\&P500 index compared to pessimistic shock. By applying intraday data, they discovered optimistic target rate shock, for example, pessimistic shock in stocks, which causes a high rate of instability in stock compared to pessimistic target shock rate. In an excessive situation, endogeneity may take place provided financial policy and stock market react concurrently to some current information. Furthermore, Bernanke and Kuttner (2005) examined FOMC decisions and its impact on day-to-day stock returns and discovered that there was no proof of irregularity. They equally carried out research in which 
they discovered a negative relationship between Federal policy tightening and extreme market returns. Christiansen and Ranaldo (2007) also revealed that there was no proof of irregular reaction based on news of relationship existing within bond and stock market.

In as much as stock prices reveal investors' anticipation on projected earnings, imperfect capital market theories show that financial reduction reflects a negative influence on prices of stock and such impact, particularly during recessions, are higher in small companies compared to big companies. Decisions of interest rate presented by the authority at the centre signify current information on macro-economy to members of the stock market. Alterations of interest rates can influence the prices of stock market differently: Firstly, it could have an impact on the rate of discount that members of the market could utilize in computing companies' current worth of projected cash flow and secondly, it could affect the expectations of firms' projected performances. The initial effect is because of the alteration of the risk-free-rate that influences companies' expected returns. There is another effect, which is because of alteration in general financial variables alongside the rate of borrowing money from the stock market. Such alterations influence the projected cash flow of market members used for predicting the current worth of a company (Bernanke \& Kuttner; Ioannids \& Kontinikas, 2008; Lobo, 2000; Khan \& Javed, 2016).

The study of Husain and Javed (2019) on stock price movement and volatility in Muscat Security Market in 9 companies shows that stock price movement is upward significantly after the dividend announcements. Abnormal return and cumulative abnormal return from the analysis are statistically significant. The result of the study confirms the dividend signaling theory as the dividend announcements have significantly impacted the share prices of the company.

In a study on volatility behaviour of S\&P BSE BANKEX return in India carried out by Khan and Javed (2017) and Javed (2018) the results indicate that S\&P BSE Bankex return volatility not only shows ARCH AND GARCH effect but also shows significant influenced by National market (SENSEX) return volatility and also influence or transmit outside shock in the International market return namely the Nasdaq and Shanghai stock Exchange.

The present study examines the impact of federal funds rate (FFR) on monthly stocks return in the United States of America. The research questions for this study are:

1) What is the influence of Federal funds rate on monthly stock return?

2) What is the impact of interest rate on monthly stock returns before and during the financial crisis?

3) Does Federal funds rate and growth rate of industrial production significantly influence monthly stock return?

\section{Methodology}

According to Burns and Grove (2003), research design is defined as a blueprint for carrying out with extreme control over components that may meddle with the legitimacy of the findings. The research design that will be adopted for this study is exploratory design for data collection and statistical analysis so as to provide answers to the research questions.

Churchill and Iacobucci (2005) noted that research design is the framework of a study, which is used as a guide for data collection and analysis. The exploratory research approach was used in this study. The exploratory research explores the nature of research problems and also involves hypotheses tests.

The study made use of secondary data from 1980-2009. The data was collected from Fred Economic Data and Economic Research Federal Reserve Bank of St. Louis. Monthly data from $31^{\text {st }}$ January 1980 to $31^{\text {st }}$ December 2009 was used in the study.

The dependent variable used in this study is the monthly stock return while the independent variables are Federal funds, Interest rate and Growth rate of industrial production.

The data was analyzed using Eviews 9.0 version software. The monthly stock return was used as the dependent variable while Federal fund rates and growth of industrial production are the independentvariables.

The Ordinary Least Square Method was used to analyse the data while the diagnostics test of residuals were carried out using the Normality Tests and Correlogram. 


\section{Data Analysis and Interpretation}

\subsection{Analysis of Questions}

3.1.1 Regression of Monthly Stock Return and Federal Funds Rate

$$
\mathrm{NSR}=\beta_{1}+\beta_{2} \mathrm{X}_{t}+e_{1}
$$

a) Estimating regression model with Xt- FEDt

The OLS result reveals that FFR does not significantly predict monthly stock return with $\mathbf{R}^{2}=-0.02,(\beta=0.054, \mathrm{t}$ $=0.93, \mathrm{p}>0.5)$.

Table 1. Ordinary Least Square estimation of monthly stock return and FFR

\begin{tabular}{lllcl}
\hline Variable & Coefficient & Std. Error & t-Statistic & Prob. \\
\hline FEDERAL_FUNDS_RATE_EFFE & 0.054763 & 0.058768 & 0.931852 & 0.3591 \\
R-squared & -0.028660 & Mean dependent var & 0.535999 \\
Adjusted R-squared & -0.028660 & S.D. dependent var & 2.235665 \\
S.E. of regression & 2.267477 & Akaike info criterion & 4.507977 \\
Sum squared resid & 149.1021 & Schwarz criterion & 4.554684 \\
Log likelihood & -66.61966 & Hannan-Quinn criter. & 4.522919 \\
Durbin-Watson stat & 2.223039 & & \\
\hline
\end{tabular}

Dependent Variable: MONTHLY_STOCK_RETURN_NSR

Method: Least Squares

Sample: 19802009

Included observations: 30

b) Estimating the regression model with $\mathrm{Xt}-\Delta \mathrm{FEDt}$

Table 2. Ordinary Least Square estimation of monthly stock return with a change in FFR

\begin{tabular}{lllll}
\hline Variable & Coefficient & Std. Error & t-Statistic & Prob. \\
\hline DELTA_FED_FED & 7.439808 & 1.747785 & 4.256707 & 0.0002 \\
R-squared & 0.347948 & & Mean dependent var & 0.535999 \\
Adjusted R-squared & 0.347948 & & S.D. dependent var & 2.235665 \\
S.E. of regression & 1.805294 & & Akaike info criterion & 4.052089 \\
Sum squared resid & 94.51347 & & Schwarz criterion & 4.098795 \\
Log likelihood & -59.78133 & & Hannan-Quinn criter. & 4.067031 \\
\hline
\end{tabular}

Dependent Variable: MONTHLY_STOCK_RETURN_NSR

Method: Least Squares

Sample: 19802009

Included observations: 30

The OLS result reveals that change in FFR significantly predict monthly stock return with $\mathrm{R}^{2}=0.347,(\beta=7.43$, $\mathrm{t}=4.256, \mathrm{p}<0.5)$. This shows that monthly stock returns increase with an increase in change in Federal funds rate with $34.7 \%$ variation explained by a change in Federal funds rate. 


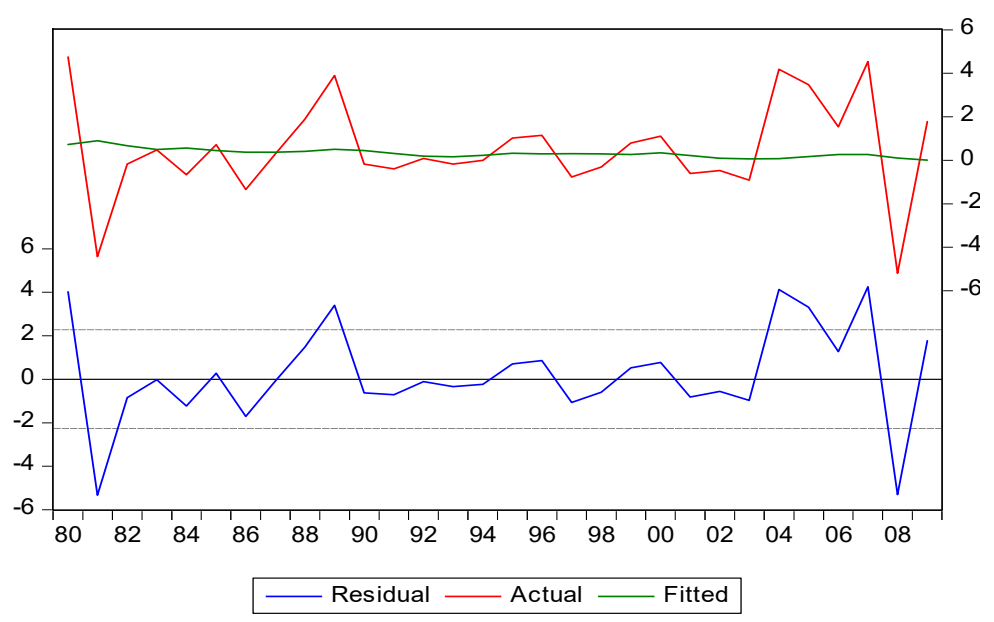

Figure 1. Actual Fitted Residual Graph for OLS estimation of monthly stock return with Federal funds rate

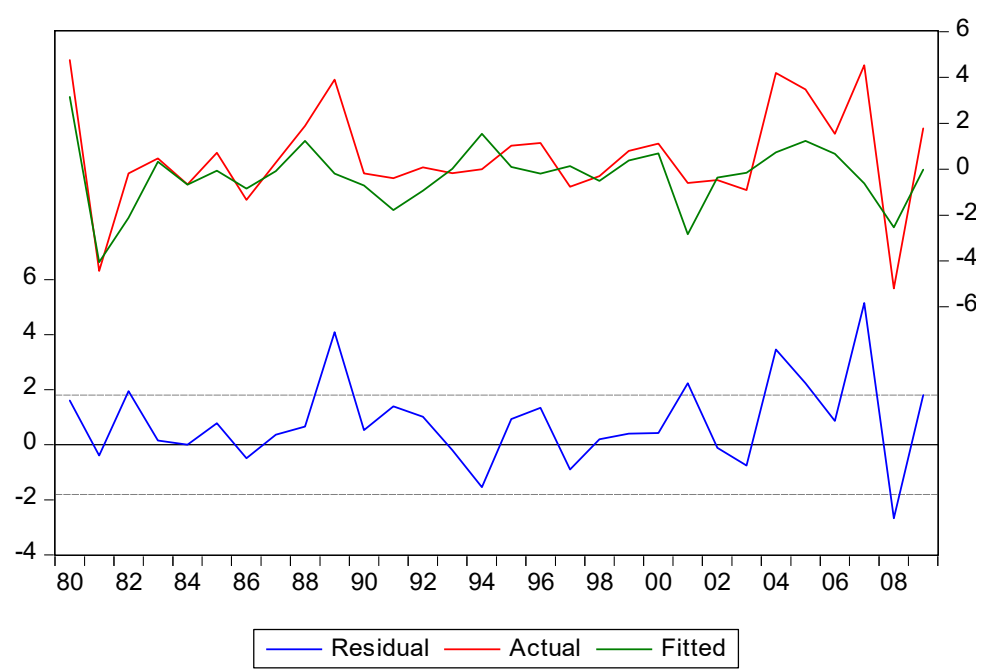

Figure 2. Actual Fitted Residual Graph for OLS estimation of monthly stock return with change in Federal funds rate

Diagnostic Testing for Residuals

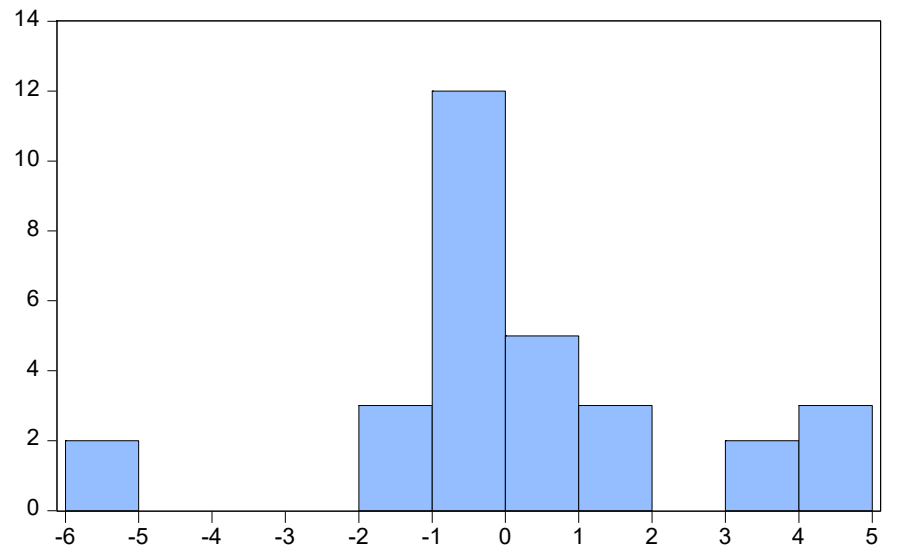

\begin{tabular}{|lr|}
\hline \multicolumn{2}{|l|}{ Series: Residuals } \\
Sample 1980 2009 \\
Observations 30 \\
Mean & 0.206227 \\
Median & -0.095318 \\
Maximum & 4.257029 \\
Minimum & -5.333666 \\
Std. Dev. & 2.257754 \\
Skewness & -0.316684 \\
Kurtosis & 3.862437 \\
& \\
Jarque-Bera & 1.431190 \\
Probability & 0.488901 \\
\hline
\end{tabular}

Figure 3. Histogram Normality Test for OLS estimation of monthly stock return and Federal funds rate 


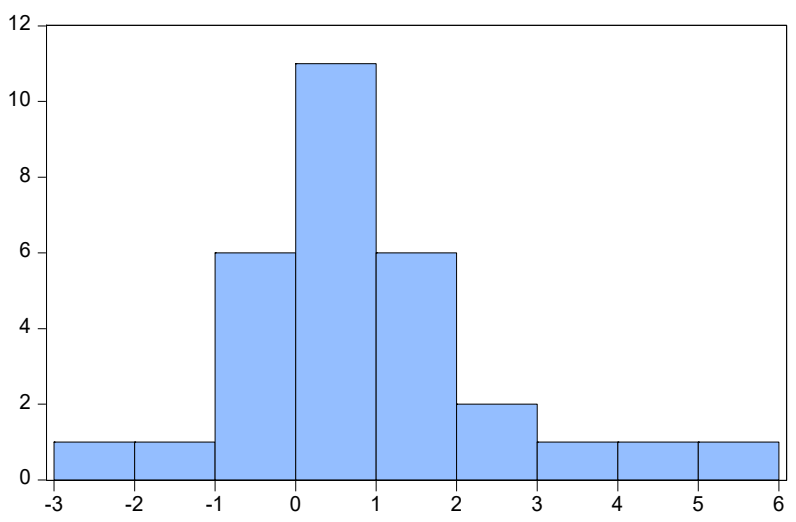

\begin{tabular}{|c|c|}
\hline \multicolumn{2}{|c|}{$\begin{array}{l}\text { Series: Residuals } \\
\text { Sample } 19802009 \\
\text { Observations } 30\end{array}$} \\
\hline Mean & 0.819125 \\
\hline Median & 0.593419 \\
\hline Maximum & 5.151876 \\
\hline Minimum & -2.669223 \\
\hline Std. Dev. & 1.601557 \\
\hline Skewness & 0.613965 \\
\hline Kurtosis & 3.953010 \\
\hline Jarque-Bera & 3.020051 \\
\hline Probability & 0.220904 \\
\hline
\end{tabular}

Figure 4. Histogram Normality Test for OLS estimation of monthly stock return and change in Federal funds rate

From the Histogram Normality Test, the OLS estimation of change in Federal funds rate has the highest mean with $(M=0.82)$ with a positive skewness of 1.60 compared to OLS estimation of Federal funds rate with a mean $(M=0.21)$ with a negative skewness of -0.32 . The result of the OLS estimation of change in federal funds rate had the best fit.

Table 3. Correlogram Squared Residuals for OLS estimation of monthly stock return and Federal funds rate

\begin{tabular}{|c|c|c|c|c|c|c|}
\hline Autocorrelation & Partial Correlation & & $\mathrm{AC}$ & PAC & Q-Stat & Prob \\
\hline . $\left.\right|^{* *} . \mid$ & . $\left.\right|^{* *} . \mid$ & 1 & 0.342 & 0.342 & 3.8658 & 0.049 \\
\hline .1 .1 & $*|\cdot|$ & 2 & -0.018 & -0.153 & 3.8775 & 0.144 \\
\hline . $\left.\right|^{*} \cdot \mid$ & . $\left.\right|^{* *}$. & 3 & 0.184 & 0.282 & 5.0781 & 0.166 \\
\hline . $\left.\right|^{*} . \mid$ & 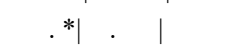 & 4 & 0.110 & -0.090 & 5.5280 & 0.237 \\
\hline .1 .1 & .1 .1 & 5 & -0.059 & -0.026 & 5.6617 & 0.341 \\
\hline$*^{*} \cdot \mid$ & $*^{*} \cdot 1$ & 6 & -0.085 & -0.098 & 5.9484 & 0.429 \\
\hline .1 .1 & .1 .1 & 7 & -0.065 & -0.037 & 6.1264 & 0.525 \\
\hline $.1 \cdot 1$ & . $\left.\right|^{*} \cdot \mid$ & 8 & 0.067 & 0.144 & 6.3240 & 0.611 \\
\hline .1 .1 &.$*||$. & 9 & -0.030 & -0.124 & 6.3660 & 0.703 \\
\hline$*^{*} . \quad \mid$ & .1 .1 & 10 & -0.099 & 0.023 & 6.8380 & 0.741 \\
\hline$*|\cdot|$ & $*|\cdot|$ & 11 & -0.108 & -0.179 & 7.4254 & 0.764 \\
\hline.$*|. \quad|$ & .1 .1 & 12 & -0.128 & -0.046 & 8.2983 & 0.761 \\
\hline.$*|\quad|$ & $. * 1 \cdot \mid$ & 13 & -0.143 & -0.087 & 9.4589 & 0.737 \\
\hline$*^{*} \cdot \quad \mid$ & $.1 \cdot 1$ & 14 & -0.149 & -0.060 & 10.793 & 0.702 \\
\hline $.1 \cdot 1$ & $.1 \cdot 1$ & 15 & -0.065 & 0.070 & 11.065 & 0.748 \\
\hline * $* \quad$. & $*$. $\quad$ | & 16 & -0.085 & -0.161 & 11.564 & 0.773 \\
\hline
\end{tabular}

Sample: 19802009

Included observations: 30

\section{Before Crisis}

$$
\gamma=\beta_{1}+\beta_{2} \Delta \mathrm{FEDt}+\mu_{\mathrm{i}}
$$

After the crisis

$$
\gamma^{*}=\beta^{*}{ }_{1}+\beta^{*}{ }_{2} \Delta \mathrm{FEDt}+\mu_{\mathrm{i}}{ }^{*}
$$

Null: $\beta_{2}=\beta_{2}{ }^{*}$ 
Table 4. Impact on the interest rate on monthly stock returns (Before crisis)

\begin{tabular}{lllll}
\hline Variable & Coefficient & Std. Error & t-Statistic & Prob. \\
\hline DELTA_FED_FED & 6.885292 & 1.544307 & 4.458499 & 0.0001 \\
R-squared & 0.364503 & Mean dependent var & 0.594581 \\
Adjusted R-squared & 0.364503 & S.D. dependent var & 1.883275 \\
S.E. of regression & 1.501310 & Akaike info criterion & 3.685615 \\
Sum squared resid & 60.85618 & Schwarz criterion & 3.733193 \\
Log likelihood & -50.59860 & Hannan-Quinn criter. & 3.700160 \\
\hline
\end{tabular}

Dependent Variable: MONTHLY_STOCK_RETURN_NSR

Method: Least Squares

Sample: 19802007

Included observations: 28

The Ordinary Least Square result reveals that before the crisis, interest rate significantly predicted monthly stock return with $\mathrm{R}^{2}=0.365,(\beta=6.89, \mathrm{t}=4.49, \mathrm{p}<0.5)$. This reveals that there is an increase in monthly stock returns with an increase in the rate of interest at $36.5 \%$ variation explained by the interest rate.

Table 5. Impact on the interest rate on monthly stock returns (During crisis)

\begin{tabular}{|c|c|c|c|c|}
\hline Variable & Coefficient & Std. Error & t-Statistic & Prob. \\
\hline DELTA_FED & -1.162539 & 24.58439 & -0.047288 & 0.9666 \\
\hline R-squared & -0.378756 & \multicolumn{2}{|c|}{ Mean dependent var } & 4.132624 \\
\hline Adjusted R-squared & -0.378756 & \multicolumn{2}{|c|}{ S.D. dependent var } & 8.207474 \\
\hline S.E. of regression & 9.637253 & \multicolumn{2}{|c|}{ Akaike info criterion } & 7.630351 \\
\hline Sum squared resid & 185.7533 & \multicolumn{2}{|c|}{ Schwarz criterion } & 7.329888 \\
\hline Log likelihood & -10.44553 & \multicolumn{2}{|c|}{ Hannan-Quinn criter. } & 7.026383 \\
\hline
\end{tabular}

Dependent Variable: MONTHLY_STOCK_RETURN

Method: Least Squares

Sample: 20072009

Included observations: 30

The Ordinary Least Square result during the crisis reveals that interest rate did not significantly predict monthly stock return with $\mathrm{R}^{2}=-0.379,(\beta=-1.163, \mathrm{t}=-0.047, \mathrm{p}>0.5)$. The relationship between and during the crisis is significantly different because, before the crisis, interest rate positively affected monthly stock return, increase in interest rate resulted into increase in monthly stock returns while during the crisis, the interest rate was not significantly related to monthly stock return.

3.2 Estimating

$$
\operatorname{NSR}=\beta_{1}+\beta_{2} \mathrm{X}_{t}+\beta_{3} \mathrm{GIND}+\mathrm{e}_{\mathrm{w}}
$$

Where GIND is the rate of growth of industrial production.

Estimating model with Federal funds rate 
Table 6. Estimating Ordinary Least Square model with Federal funds rate and GIND

\begin{tabular}{lllcl}
\hline Variable & Coefficient & Std. Error & t-Statistic & Prob. \\
\hline FEDERAL_FUNDS_RATE_EFFE & 0.021377 & 0.058270 & 0.366863 & 0.7165 \\
GROWTH_RATE_OF_INDUSTRIA & 2.171010 & 1.074889 & 2.019753 & 0.0531 \\
R-squared & 0.102150 & Mean dependent var & 0.535999 \\
Adjusted R-squared & 0.070084 & S.D. dependent var & 2.235665 \\
S.E. of regression & 2.155900 & \multicolumn{2}{c}{ Akaike info criterion } & 4.438634 \\
Sum squared resid & 130.1414 & Schwarz criterion & 4.532048 \\
Log likelihood & -64.57952 & Hannan-Quinn criter. & 4.468518 \\
\hline
\end{tabular}

Dependent Variable: MONTHLY_STOCK_RETURN_NSR

Method: Least Squares

Sample: 19802009

Included observations: 30

The Ordinary Least Square (OLS) result reveals that only growth rate of industrial production significantly predicted monthly stock return with $(\beta=2.17, \mathrm{t}=2.02, \mathrm{p}<0.5)$ and Federal funds rate did not significantly predict monthly stock return. Also, $\mathrm{R}^{2}=0.10$, which implies that $10.0 \%$ disparity in monthly stock return is revealed by FFR and growth rate of industrial production.

Table 7. Estimating Ordinary Least Square model with change in FFR and GIND

\begin{tabular}{lllcl}
\hline Variable & Coefficient & Std. Error & t-Statistic & Prob. \\
\hline DELTA_FED_FED & 6.635618 & 1.859506 & 3.568485 & 0.0013 \\
GROWTH_RATE_OF_INDUSTRIA & 1.102348 & 0.918279 & 1.200450 & 0.2400 \\
R-squared & 0.379865 & Mean dependent var & 0.535999 \\
Adjusted R-squared & 0.357717 & S.D. dependent var & 2.235665 \\
S.E. of regression & 1.791719 & Akaike info criterion & 4.068569 \\
Sum squared resid & 89.88724 & Schwarz criterion & 4.161982 \\
Log likelihood & -59.02853 & Hannan-Quinn criter. & 4.098453 \\
\hline
\end{tabular}

Dependent Variable: MONTHLY_STOCK_RETURN_NSR

Method: Least Squares

Sample: 19802009

Included observations: 30

The OLS in table 7 reveals that change in FFR significantly predicted monthly stock return with $(\beta=6.64, \mathrm{t}=$ $3.57, \mathrm{p}<0.5)$ while the growth rate of industrial production did not significantly predict monthly stock return. Also, $\mathrm{R}^{2}=0.37$, which shows that $37.0 \%$ variation in monthly stock return is explained by a change in FFR and growth rate of industrial production. This shows that the change in FFR and growth rate of industrial production explained a significant amount of variation in monthly stock return compared to FFR and growth rate of industrial production.

\section{Discussion of Findings}

The study examined the effect of FFR on monthly stock returns in the United States within the period of 1980-2009 and the Ordinary Least Square Method was applied to perform the analysis. The result of the first question shows that FFR does not significantly predict monthly stock return while the change in FFR significantly predicted monthly stock returns. In addition, findings reveal that before the crisis, the rate of interest significantly predicted monthly stock return, which shows that monthly stock returns increase with an increase in interest rate with $36.5 \%$ variation explained by the interest rate. Conversely, during the crisis, the rate of interest did not significantly predict monthly stock return. This finding agrees with the study of Gagnon et al. (2011).

In addition, the growth rate of industrial production significantly predicted monthly stock return with while FFR did not significantly predict monthly stock return. Likewise, change in FFR significantly predicted monthly 
stock return while the growth rate of industrial production did not significantly predict monthly stock return. This result agrees with the work of Petri and Vataja (2011) who reported a bi-directional causality within interest rate and stock market returns. Applying monthly data sourced from 1987 - 2010, the study showed that during a crisis-free period, interest rate grangers reflects volatility in stock prices, while the second granger causes the former in the period of disorderliness.

The findings of Kurov (2010) characteristically revealed a better stock market rebound when financial increase concur with poor economic growth and reduction in credit market situations. Ever since the 2007-2009 financial crises was typified with the credit crisis, recession and an extraordinary decline in general economic situations, a strongly negative FFR coefficient shockwere expected within that time.

Increasing demand for stocks will raise their prices and consequently lead to a higher higher investment. The wealth effects illustrate that it is the lifetime resources of consumers that determines consumption spending rather than just today is income. Therefore, when the prices of stock go up, the worth of wealth also increases and which give rise to the consumption rate. Monetary policy is likely to impact stock prices through interest rate channel. The modern financial theory posits that stock price is equivalent to the current worth of projected future cash flow minimized by a suitable rate of discount. The increase in interest rate, which indicates the higher discount rate, could cut the stock price directly. In other words, deflation in monetary policy, which implies the increase of interest rate in general, would lead to the fall of stock price. In the meanwhile, the rising cost of financing caused by the deflation in monetary policy also could decrease the expected future cash flow. In conclusion, findings show that before the crisis, there was a significant relationship between interest rate and monthly stock returns while after the crisis, there was no significant relationship between the two variables.

\section{Implications and Limitation}

The correlation between stock returns as well as financial risk criteria such as changes in interest rate could furnish managers of financial institutions as well as financial regulators with adequate information on how to improve stock market returns via proper management of volatility of interest rates. In addition, financial markets that pegged their currencies to US dollar or other major currencies have to ensure that they closely monitor the effect of macroeconomic variables like inflation and interest rates so as to ensure foreign policies does not have significant influence on their financial market.

This study did not put into consideration other financial risk parameters such as inflation rate, exchange rate etc, therefore the findings may be limited to the scope of interest rate and federal funds.

\section{References}

Bernanke, B. S., \& Kuttner, K. N. (2005). What explains the stock market's reaction to Federal Reserve Policy? Journal of Finance, 60, 1221-1257. https://doi.org/10.1111/j.1540-6261.2005.00760.x

Bomfim, A. N. (2003). Pre-announcement effects, news, and volatility: Monetary policy and the stock market. Journal of Banking and Finance, 27, 133-151. https://doi.org/10.1016/S0378-4266(01)00211-4

Burns, N., \& Grove, S. K. (2003). Understanding research (3rd ed.). Philadelphia, W.B. Saunders Company.

Christiansen, C., \& Ranaldo, A. (2007). Realized bond-stock correlation: macroeconomic announcement effects. Journal of Futures Markets, 27, 439-469. https://doi.org/10.1002/fut.20258

Churchill, G. A., \& Iacobucci, D. (2005). Marketing research: methodological foundation (9th ed.). Thomson/South-Western, Cincinnati, $\mathrm{OH}$.

Gagnon, J., Raskin, M., Remache, J., \& Sack, B. (2011). The Financial Market Effects of the Federal Reserve's Large Scale Asset Purchases. International Journal of Central Banking, 7, 3-43.

Husain, U., \& Javed, S. (2019). Stock Price Movement And Volatility In Muscat Security Market (Msm). International Journal of Research - Granthaalayah, 7(2), 68-84. https://doi.org/10.5281/zenodo.2580535

Ioannidis, C., \& Kontonikas, A. (2008). The impact of monetary policy on stock prices. Journal of Policy Modeling, 30(1), 33-53. https://doi.org/10.1016/j.jpolmod.2007.06.015

Javed, S. (2018). Does Organisation Behaviour Affect Performance Of Auditing Firms? https://doi.org/10.5281/zenodo.1171842

Khan, A. A., \& Javed, S. (2017). International Journal of Advanced and Applied Sciences a study of volatility behaviour of S \& P BSE BANKEX return in India: A pragmatic approach using GARCH model. https://doi.org/10.21833/ijaas.2017.04.018

Khan, A., \& Javed, S. (2016). Determining Factors Responsible in Shifting Consumption of Mobile Data (2G to 
3G). https://doi.org/10.5120/ijca2016912452

Kurov, A. (2010). Investor sentiment and the stock market's reaction to monetary policy. Journal of Banking and Finance, 34, 139-149. https://doi.org/10.1016/j.jbankfin.2009.07.010

Lobo, B. J. (2000). Asymmetric Effects of Interest Rate Changes on Stock Prices. Financial Review, 35(3), 125-144. https://doi.org/10.1111/j.1540-6288.2000.tb01424.x

Petri, K., \& Vataja, J. (2011), the role of stock markets Vs. The term spreading forecasting macrovariables in Finland. The Quarterly Review of Economics and Finance, 51, 124-132. https://doi.org/10.1016/j.qref.2011.01.005

Sarfaraz, J. (2017). Journal of Internet Banking and Commerce unified theory of acceptance and use of technology (utaut) model-mobile banking. Journal of Internet Banking and Commerce, 22(3), 1-20.

\section{Copyrights}

Copyright for this article is retained by the author(s), with first publication rights granted to the journal.

This is an open-access article distributed under the terms and conditions of the Creative Commons Attribution license (http://creativecommons.org/licenses/by/4.0/). 